\title{
Integration of Solar Chimney Power Plant with Photovoltaic for Co-Cooling, Power Production, and Water Desalination
}

\author{
Malek Alkasrawi ${ }^{1,2, *}$, Emad Abdelsalam ${ }^{2} \mathbb{D}$, Hamza Alnawafah $^{2} \mathbb{D}$, Fares Almomani ${ }^{3} \mathbb{D}_{\text {, }}$ \\ Muhammad Tawalbeh 4 (D) and Aya Mousa ${ }^{2}$ \\ 1 Department of Chemistry, Carthage College, University of Wisconsin Parkside, Kenosha, WI 54481, USA \\ 2 Electrical and Energy Engineering Department, Al Hussein Technical University, Amman 11831, Jordan; \\ Emad.Abdelsalam@htu.edu.jo (E.A.); Hamza.Nawafah@htu.edu.jo (H.A.); Aya.Mousa@htu.edu.jo (A.M.) \\ 3 Chemical Engineering Department, Qatar University, Doha P.O. Box 2713, Qatar; Falmomani@qu.edu.qa \\ 4 Sustainable and Renewable Energy Engineering Department (SREE), University of Sharjah, \\ Sharjah P.O. Box 27272, United Arab Emirates; mtawalbeh@sharjah.ac.ae \\ * Correspondence: alkasraw@uwp.edu
}

Citation: Alkasrawi, M.; Abdelsalam, E.; Alnawafah, H.; Almomani, F.; Tawalbeh, M.; Mousa, A. Integration of Solar Chimney Power Plant with Photovoltaic for Co-Cooling, Power Production, and Water Desalination. Processes 2021, 9, 2155. https:// doi.org/10.3390/pr9122155

Academic Editor: Mattia De Rosa

Received: 31 August 2021

Accepted: 12 November 2021

Published: 29 November 2021

Publisher's Note: MDPI stays neutral with regard to jurisdictional claims in published maps and institutional affiliations.

Copyright: (c) 2021 by the authors. Licensee MDPI, Basel, Switzerland. This article is an open access article distributed under the terms and conditions of the Creative Commons Attribution (CC BY) license (https:// creativecommons.org/licenses/by/ $4.0 /)$.

\begin{abstract}
This work explores the technical possibilities of increasing the efficiency of a standard solar chimney power plant (SCPP) by integrating it with photovoltaic (PV) panels. The integration is possible by using the collector circumference to install the PV collectors, which provide a heat sink, allow for the better harvesting of the solar radiation, and increase energy production. The new design led to an increase in the annual electricity production from 380 to $494 \mathrm{MWh}$ and water production from 278 to $326 \mathrm{k}$ tons/year compared with the standard SCPP, marking an increase of $30 \%$ and $17 \%$, respectively. The results also show that the integration reduced the greenhouse gas emissions (GHG), the localized cost of energy, and the capital cost of investment by $30 \%, 36 \%$, and $20 \%$, respectively. The proposed design supports the sustainable replacement of the existing desalination plants with zero operational costs and an excellent reduction in greenhouse gas emissions.
\end{abstract}

Keywords: solar water distillation; solar chimney; cooling tower; photovoltaic cooling

\section{Introduction}

The increase in the world's population has increased the demand for energy, food, and water [1]. The finite resources of fossil fuel have shown a serious impact on the environment and have encouraged the search for new, cost-effective, and renewable energy systems [2]. Solar energy has the potential to provide a clean and free source of energy in the form of electricity or hot water [3,4]. However, the fabrication of solar systems, such as photovoltaics cells, utilizes a wide range of chemicals that add to the final cost and may exhibit a negative environmental impact on the ecosystem [5]. Therefore, there is a need for new technologies that use less or no chemicals, have simple designs, and have minimum maintenance costs.

Besides the energy challenges, water scarcity and shortages have become a global problem and are expected to increase with time [6,7]. Significant efforts are focusing on the development of new and novel technologies that offer a sustainable solution for the energy and water problems [8,9]. Seawater desalination is considered one of the promising solutions to provide clean water $[10,11]$. Several successful commercial projects around the world produce water via a membrane and thermal desalination [12]. However, the major concerns of water desalination technologies are the high energy demand and the high emissions of greenhouse gas (GHG) [13]. Hence, introducing a novel technology for water desalination with minimum or no energy consumption would make seawater desalination feasible, durable, and sustainable.

The solar chimney (SC) concept introduced late in the 1970s offers an opportunity to provide free-of-charge electrical power. The SC concept depends on the use of solar 
irradiation to create a natural draft of air inside the chimney due to the difference in air density between the hot and cold sections $[14,15]$. The first design of the solar chimney power plant (SCPP) was introduced by Schlaich [16] in 1978. The design consists of collectors made of transparent materials, such as glass, wind turbines, and chimneys. The SCPP may contain other compartments depending on the proposed design, such as a seawater basin for desalination. The solar radiation warms up the collector and heats the air that enters the SCPP. The heating process develops differential air density between the inside and outside of the collector and induces the air to flow inside the SCPP. Therefore, the air gains kinetic energy, moves inside the chimney, and passes through a turbine to generate electricity.

Recent developments on the SCPP have focused on (1) exploring alternative designs to maximize the power output or (2) improving the overall system efficiency or lowering the capital cost. For example, several articles discussed the integration of the SCP with seawater desalination [17-20]. The water absorbs heat collected by the solar radiation in the form of heat to vaporize and later be condensed after leaving the turbine and reaching the dew point temperature. Kiwan et al. [19] studied several design alternatives that integrated PV with SCPP to achieve the cooling of the PV, generate additional electricity, and maximize the amount of freshwater. Other studies focused on maximizing thermal efficiency by integrating the SCPP with the cooling tower (CT) concept [18]. Process simulation was generally used to investigate how to improve the overall efficiency and lower the capital cost of the SCPP [21,22]. Abdelsalam et al. 2021 [18] developed a novel hybrid design that combines the SCPP with a CT. The new design was able to produce an annual 481,440 kWh of electricity and 123,753 tons of desalinated water at a levelized cost of energy (LCOE) of $\$ 1.86 / \mathrm{kWh}$. Kiwan et al. [20] studied integrating PV panels with an SCPP. The proposed system used the solar chimney for the direct evaporation of water and extracted the energy from the wet air stream. The system efficiency was $71 \%$ compared with $1 \%$ for the conventional. Zuo et al. [23] integrated a wind supercharging device at the top of the solar chimney to harvest additional electrical power from the updraft wind exiting the chimney. The performance of the system and the energy efficiency was increased by $15.4 \%$. In addition, the hourly freshwater yield, power generation, and comprehensive efficiency reached $193.7 \mathrm{~kW}, 17.2$ ton $/ \mathrm{h}$, and 13.5\%, respectively. Furthermore, Abdelsalam et al. [24] proposed a novel design structure of double co-centric chimneys where one of the chimneys was used as an SCPP while the other chimney was partitioned into 10 cooling towers. The system produced up to $993 \mathrm{MWh}$ of electrical energy, which is 2.6 times higher than the traditional SCPP (377 MWh). The thermal efficiency of this design was $1.6 \%$, which is 200 times greater than the conventional SCPP.

The previous literature review revealed that a stand-alone SCPP suffers from high capital investment and low efficiency. Therefore, a hybrid design would help improve the overall efficiency, reduce the total capital cost, and enhance the process economics. Therefore, the present paper illustrates a novel opportunity to develop a unique hybrid design consisting of the integration between the photovoltaics (PV) cells and SCPP. In such a design, the PV panels will be connected to the circumference of the SCPP collector. The scope of the work is to assess utilizing the excess heat generated from the PV panels to further heat the air entering the collector and increase the kinetic energy of the air within the SCCP to produce more electrical power. This design configuration will offer a sustainable energy system that generates desalinated seawater, reduces the GHG, and decreases the localized cost of energy. In addition, the entering air will be used to cool the PV panels and increase their efficiency.

\section{Materials and Methods}

\subsection{PV Integrated with SCPP Description}

The structure of the PV integrated with SCPP (PV-SCPP) is shown in Figures 1 and 2. Figure 1a shows a 3D view of the structure where the main components are labeled. Figure $1 \mathrm{~b}$ shows a cross-section view of the structure, labeled with dimensions, showing 
the main components and the direction of airflow. The PV-SCPP is divided into four zones: PV cooling zone, air heating zone, water evaporation zone, and chimney zone. The PV zone is the area under the PV panels, while the air heating zone is the area under the collector starting from the entrance to the edge of the seawater pool. The water evaporation zone is the area under the collector that starts at the beginning of the seawater pool and ends at the center of the chimney.

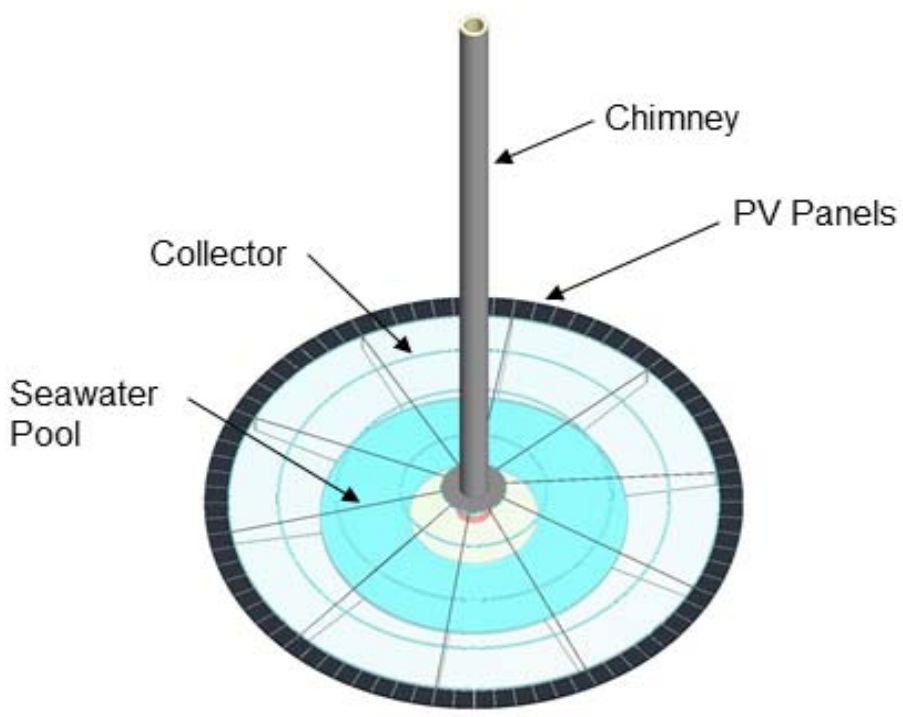

(a)

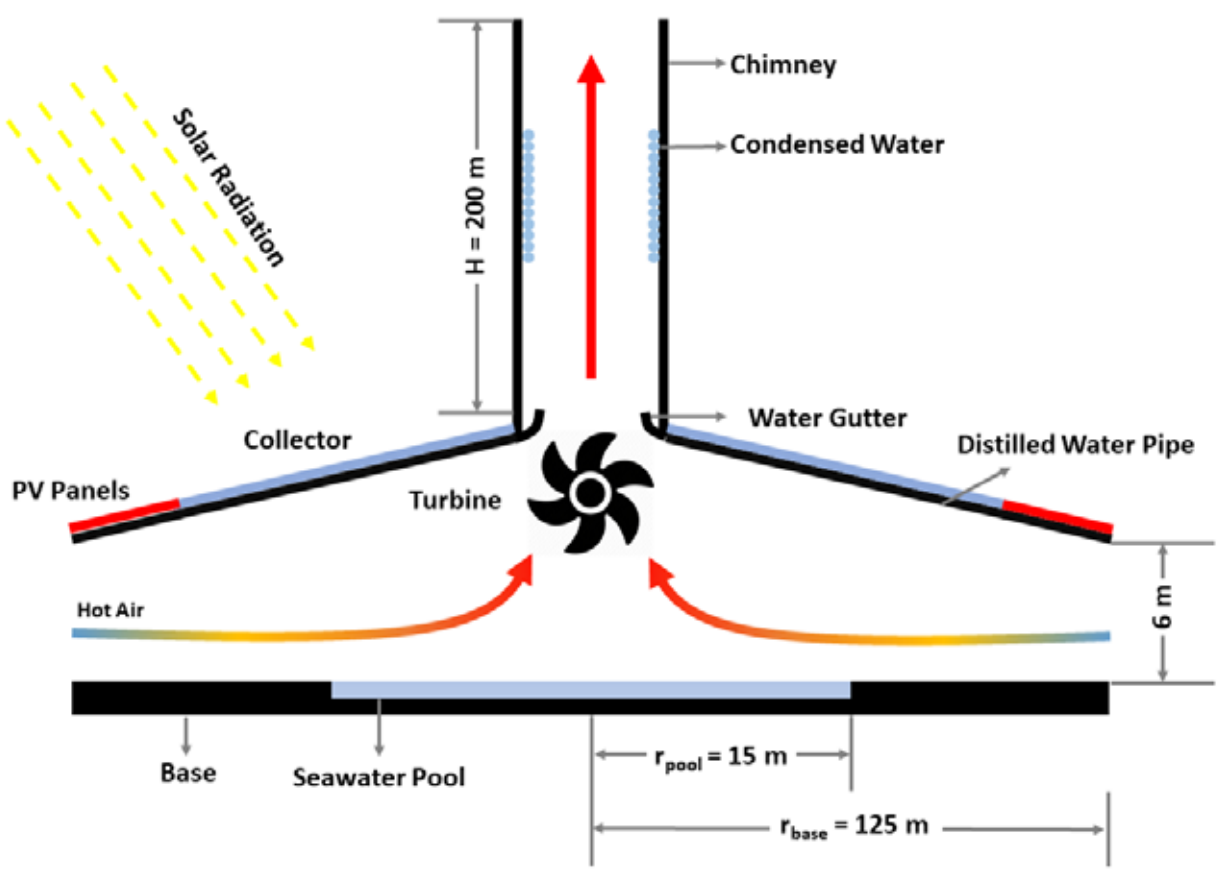

(b)

Figure 1. Illustration of the proposed SCPP integrated with PV (dark circumference): (a) 3D view, and (b) cross-section view. 


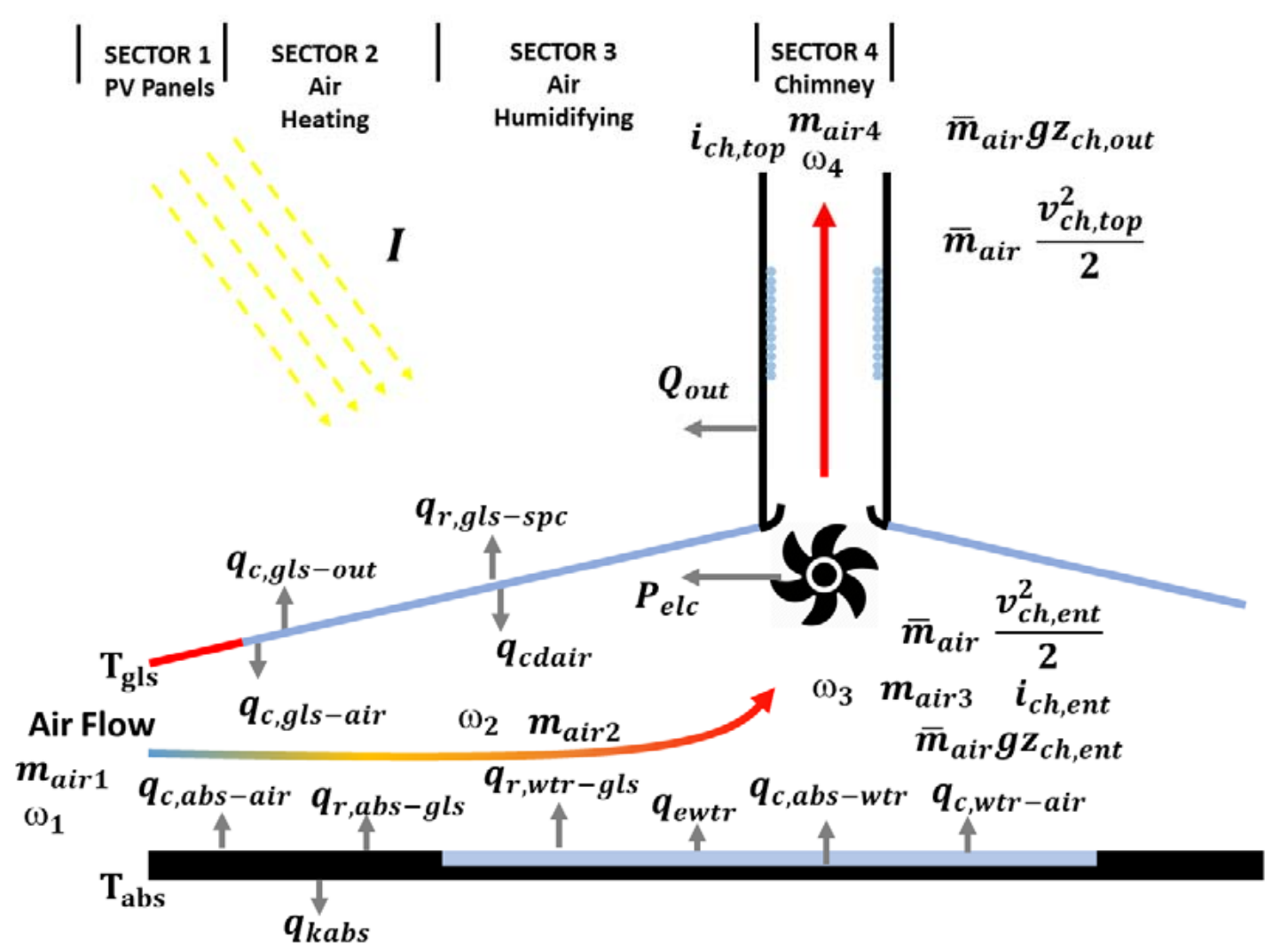

Figure 2. Diagrams to represent the energy balance equations showing sector 1, sector 2, and sector 3 of the PV-SCPP.

The chimney zone is the SCPP chimney column. The new design of PV-SCPP is like the SCPP with bolts-on PV panels connected to the circumference of the SCPP's collector. Hence, the PV-SCPP combines PV panels, collector, base, water pool, chimney, a power conversion unit, and a turbine. The collector is the main component of the solar chimney power plant, and it acts as a heat exchanger by converting solar energy into thermal energy, thereby generating the greenhouse effect that raises the temperature of the air passing underneath it. The roof of the solar collector is divided into two parts, the outer edge that is covered with PV panels and the rest of the collector, which is made of transparent material. As aforementioned, the purpose of integrating the PV panels with the SCPP is to improve the electricity production from the system. However, due to the high solar radiation, the temperature of the PV panels would increase noticeably, especially in hot climates. This leads to a drop in the electrical efficiency of the panels and, consequently, reduces electricity production. Installing PV panels at the inlet of the collector allows them to exchange heat with the cold air entering the collector. This would not only provide a cooling technique for the PV panels and improve their efficiency but also contribute to the heating of the air. The rest of the roof is made of a transparent material, such as glass or plastic, and placed at a certain height above the ground to originate a flow channel for the air. The collector allows the absorption of both beam and diffuse solar radiation. Hence, SCPPs can operate under clear or cloudy skies. The height of the roof increases gradually from the outer edge toward the center to minimize the fraction. A major part of the solar radiation transmits through the transparent section of the roof and is absorbed by the ground, whereas the remaining part is either reflected or absorbed inside the roof. Typically, the transparent roof transmits short-wavelength radiation from the sun and prohibits the transmission of the long-wavelength radiation that radiates from the ground. This, in turn, further enhances the heating of the air. Moreover, the ground soil (concrete) beneath the roof serves as a short-term thermal storage material to store the thermal energy during the day and discharge it during the night. This allows SCPPs to overcome the intermittency of solar radiation and generate power all year round. 
The other main components of the SCPP are the chimney and the turbine. The chimney is located at the center of the collector and works as the heat engine of the power plant. The chimney generates the difference in temperature between the heated air incoming from the collector and the cold air at the top of the chimney. This leads to the chimney effect, which drives the flow of the air from the bottom to the top of the chimney. On the other hand, the turbine converts the energy of the hot air into rotational mechanical energy and delivers it to the generator where it converts it to electrical energy. The design of the solar chimney turbine is like a typical wind turbine. Furthermore, the turbine will be preserved from harsh weather and the fluctuations of the weather conditions with no change of the airflow direction, even though the turbine must withstand higher temperatures and pressure drops [17-19,25]. The large volume of the collector also provides a buffer zone and protects the turbine from air speed fluctuations. The turbine is mounted at the lowest part of the chimney where the density gradient inside and outside the chimney is the main driving force. Air also passes over the pool of the seawater as it approaches the base of the chimney and evaporates part of the water and increases its humidity. The hot and humid air enters the base of the chimney and drives the turbine-generator system to produce electricity. The electricity generated is directly proportional to the pressure drop across the turbine and the volumetric flow rate of air. Afterward, hot and humid air rises in the chimney and exchanges the heat with the inner walls, where the temperature and relative humidity decrease, leading to water condensation at the walls of the chimney. The condensed water falls and accumulates in a basin area at the bottom of the chimney. In this study, the characteristics of the seawater are similar to that found in Qatar seaports, where the remaining brine would be pumped back to the sea. The main proposed location was simulated to Qatar's condition due to the high availability of solar radiation and the need for desalinated water.

\subsection{Mathematical Model}

A mathematical model has been developed to evaluate the performance of the new system. The new system was described by a set of equations that are based on the mass and energy balance over the entire PV-SCPP system (Figure 2). Several assumptions were considered during the development of the model, such as steady-state operation, symmetrical airflow, no friction losses, constant local temperature, and uniform and constant level of the water pool.

Equations (1)-(22) were derived to depict the four zones of the PV-SCPP system. A program was built with MATLAB R2013a to simulate and numerically solve these Eqs. The program utilizes a genetic iterative algorithm that is built in MATLAB to solve temperature variation throughout the entire system with a convergence criterion of $10^{-6}$. The hourly weather data (ambient temperature, local wind speed, solar radiation, and relative humidity) were supplied to the program through an input file and processed point by point. The computational time was approximately $3.3 \mathrm{~s}$ for each data entry; hence, the computational time needed to run for one year, i.e., 8760 data points, was around $8 \mathrm{~h}$. The dimensions of the PV-SCPP system and the thermal-radiative properties for glass, water, and base were displayed in Tables 1 and 2, respectively. The values in the tables were selected based on the work by Schlaich [16] and the study done by Kiwan [19,20]. The mathematical model for the SCPP has been validated in our previous published work $[19,22]$.

Table 1. Dimensions of the PV-SCPP system.

\begin{tabular}{cc}
\hline Parameter & Dimension $(\mathbf{m})$ \\
\hline Collector Diameter & 250 \\
Collector Entrance Height & 6 \\
Chimney Height & 200 \\
Chimney Diameter & 10 \\
Depth of Seawater Pool & 0.03 \\
\hline
\end{tabular}


Table 1. Cont.

\begin{tabular}{cc}
\hline Parameter & Dimension $(\mathbf{m})$ \\
\hline Length of the PV module. & 2 \\
Width of the PV module. & 1 \\
Thickness of PV glass cover. & 0.0032 \\
Thickness of PV Tedlar & 0.0005 \\
Thickness of solar cell & 0.0003 \\
\hline
\end{tabular}

Table 2. Properties of material used in PV-SCPP system.

\begin{tabular}{ccccc}
\hline \multirow{3}{*}{ SCPP } & Material & Transmissivity $(\tau)$ & Emissivity $(\varepsilon)$ & Absorptivity $(\alpha)$ \\
& Glass & 0.90 & 0.90 & 0.05 \\
& Water & 0.90 & 0.95 & 0.05 \\
\multirow{2}{*}{ PV } & Base & 0.95 & 0.95 & 0.95 \\
& Glass & 0.84 & 0.94 & 0.06 \\
& Tedlar & 0.012 & 0.02 & 0.8 \\
\hline
\end{tabular}

Sector 1: PV.

The temperature of the air under the PV panels was calculated by calculating the temperature at each layer of the PV panels based on solar radiation and outside temperature.

Equation (1) was used to determine the temperature for the PV glass cover [26]:

$$
M_{g l s} C_{g l s} \frac{d T_{g l s}}{d t}=A_{m}\left[\alpha_{g l s} I+h_{r . s k y-g l s}\left(T_{s k y}-T_{g l s}\right)+\alpha_{g l s} I+h_{c o n, a i r}\left(T_{a i r}-T_{g l s}\right)-\alpha_{g l s} I+h_{c o n . g l s}\left(T_{g l s}-T_{c e l l}\right)\right.
$$

where:

$T_{g l s}$ is the temperature for the PV glass cover.

$T_{\text {cell }}$ is the temperature of the PV at the cell layer

$M_{g l s}$ is the mass of glass

$\mathrm{C}_{g l s}$ is the heat capacity of glass

The equivalent temperature of the sky was given by Equation (2) [26]:

$$
T_{\text {sky }}=0.0552 T_{\text {air }}^{1.5}
$$

The PV solar cell temperature (in Kelvin and Celsius) was given by Equations (3) and (4), respectively [26]:

$$
\begin{gathered}
T_{\text {Cell }_{k}}=T_{\text {air }}+( \\
T_{\text {Cell }_{C}}=T_{\text {Cell }_{k}}-273
\end{gathered}
$$

The radiative heat transfer coefficient between the glass cover of the PV module and the sky can be given by Equation (5) [26]:

$$
h_{r, s k y-g l s}=\sigma \varepsilon_{g l s} \frac{\left(T_{g l s}^{2}-T_{s k y}^{2}\right)\left(T_{c e l l_{k}}^{2}+T_{s k y}^{2}\right)}{T_{g l s}-T_{a i r}}
$$

The convective heat coefficient due to the wind is described by Equation (6) [26]:

$$
h_{\text {con, air }}=5.7+3.8 V_{w}
$$

The temperature for the PV Tedlar layers was solved using Equation (7) [26]:

$$
M_{t e d} C_{t e d} \frac{d T_{t e d}}{d t}=A_{m}\left[\tau_{\text {ted }} \alpha_{t e d} I(1-\beta)+h_{c n d, t}\left(T_{c e l l} k-T_{t e d}\right)+h_{c o n, f-t e d}\left(T_{t e d}-T_{f}\right)-h_{c, \text { air }}\left(T_{\text {ted }}-T_{\text {air }}\right)\right.
$$


where:

$T_{\text {ted }}$ is the temperature for the PV Tedlar

$T_{f}$ is the temperature of the air under the PV panels

$h_{c n d, \text { ted }}$ is the heat conductivity of PV Tedlar

The radiative heat transfer coefficient between the cell and the Tedlar is determined by Equation (8) [26]:

$$
h_{r, \text { cell-ted }}=\sigma \frac{\left(T_{\text {cell }}-T_{\text {ted }}\right)\left(T_{\text {cell }}^{2}+T_{\text {ted }}^{2}\right)}{\frac{1}{\varepsilon_{\text {cell }}}+\frac{1}{\varepsilon_{\text {ted }}}-1}
$$

\subsubsection{Sector 2: Solar Air Heating}

Equation (9) through 22 represent the mass of energy balance of the entire design. The heat balance represents the heat content and profile of the moving air via different zones of the SCPP.

Airflow:

The temperature profile of the air under the collector is dependent on the convective heat transfer between the glass and air, and absorber and air. The energy balance of the air flowing under the collector is as follows:

$$
q_{c, g l s-a i r}+q_{c, a b s-a i r}=-\frac{c_{p, a i r} \bar{m}_{a i r}}{2 \pi r} \frac{d T_{a i r}}{d r}
$$

where $\omega_{1}=\omega_{2}$.

Absorber:

The energy balance equation at the absorber is as follows:

$$
q_{r, a b s-g l s}+q_{c, a b s-a i r}+q_{k a b s}=\alpha_{a b s} \tau_{g l s} I
$$

Collector:

The energy balance equation at the collector is as follows:

$$
q_{c, g l s-o u t}+q_{c, g l s-a i r}+q_{r, g l s-s p c}=\alpha_{g l s} I+q_{r, a b s-g l s}
$$

2.2.2. Sector 3: Water Evaporation

Airflow:

$$
q_{c, g l s-a i r}+q_{c, w t r-a i r}=-\frac{c_{p, a i r} \bar{m}_{\text {air }}}{2 \pi r} \frac{d T_{a i r}}{d r}
$$

Absorber:

$$
q_{c, a b s-w t r}+q_{k a b s}=\alpha_{g l s} \tau_{w t r} \tau_{g l s} I
$$

Collector roof:

$$
q_{r, g l s-s p c}+q_{c, g l s-o u t}=q_{c, g l s-a i r}+q_{r, w t r-g l s}+\alpha_{g l s} I
$$

The water energy balance equation is given by:

$$
q_{e w t r}+q_{r, w t r-a i r}+q_{c, w t r-a i r}+c_{p, w t r} \bar{m}_{w t r} \frac{d T_{w t r}}{d t}=q_{c, a b s-w t r}+\alpha_{w t r} \tau_{g l s} I
$$

As the air expands under the collector and enters the chimney, the velocity of the air can be calculated using the following equation:

$$
V_{c h}=\sqrt{2 g H_{c h} \frac{T_{\text {ch,ent }}-T_{\text {out }}}{T_{\text {out }}}}
$$


The turbine output power can be calculated as follows [27]:

$$
P_{e l c}=\frac{1}{2} \rho_{e n, c h} C_{f} A_{c h} V_{c h}^{3}
$$

where $C_{f}$ is the turbine efficiency, 0.63 .

\subsubsection{Sector 4: Solar Chimney}

$$
P_{\text {elc }}+Q_{\text {out }}=\bar{m}_{\text {air }}\left[\left(\frac{v_{c h, e n t}^{2}}{2}+g z_{c h, e n t}+i_{c h, e n t}\right)-\left(\frac{v_{c h, o u t}^{2}}{2}+g z_{c h, o u t}+i_{c h, o u t}\right)\right]
$$

where

$$
Q_{\text {out }}=\bar{m}_{\text {air }}\left[\left(i_{\text {ch,ent }}-i_{\text {ch,out }}\right)-\left(\omega_{4}-\omega_{3}\right) i_{\text {wtr }}\right]
$$

The water condensation mass flow rate is given by:

$$
\bar{m}_{w t r}=\bar{m}_{a i r}\left(\omega_{4}-\omega_{3}\right)
$$
follows:

The enthalpy [28] of the moist air entering the chimney $\left(i_{c h, e n t}\right)$ can be calculated as

$$
i_{\text {ch,ent }}=T_{\text {air }}+\omega_{3}\left(2501.3+1.86 T_{\text {air }}\right)
$$

The efficiency of the SCPP can be calculated as follows:

$$
\eta=\frac{P_{\text {elc }}}{\frac{1}{4} \pi\left(D_{c o l}^{2}-D_{c h}^{2}\right) I}
$$

\section{Results and Discussion}

\subsection{Weather Profile}

The hourly weather conditions (temperature, wind speed, solar irradiation, and relative humidity) were collected from a local weather station at Doha International Airport, Doha, Qatar (latitude: $25^{\circ} 17^{\prime} 9.9816^{\prime \prime} \mathrm{N}$, longitude: $51^{\circ} 32^{\prime} 5.3412^{\prime \prime} \mathrm{E}$ ). The profile of one complete day of operation in June 2020 (Figure 3) showed that the solar radiation commenced in the early morning, 5:00, with low limited intensity $\left(287 \mathrm{~W} / \mathrm{m}^{2}\right)$ until it reached the maximum value during noontime $\left(857 \mathrm{~W} / \mathrm{m}^{2}\right)$.

Later, the solar radiation started slowly to decrease at $15: 00\left(646 \mathrm{~W} / \mathrm{m}^{2}\right)$ and approached zero by the sunset. The range of solar irradiation was recorded from 50 to $880 \mathrm{~W} / \mathrm{m}^{2}$, with an estimated average value of $314.3 \mathrm{~W} / \mathrm{m}^{2}$. According to Figure 3, it was interesting to observe that the solar radiation during the entire daytime follows the normal distribution profile. This is an interesting and important pattern since it guarantees a uniform average power production. As typical of a coastal city, we observed a variation of the wind speed at different times of the day in the range of 2.1 to $6.7 \mathrm{~m} / \mathrm{s}$, and, occasionally, large variations during the night, with an average value of $\sim 3.7 \mathrm{~m} / \mathrm{s}$. The hourly changes in the solar radiation and wind speed were combined with changes in the relative humidity ranging from 20 to $67 \%$.

\subsection{Baseline: Electricity and Water Productions without the PV Panels}

Figure $4 \mathrm{~A}, \mathrm{~B}$ represents the overall electrical energy and desalinated water production of the SCPP with and without the PV cells. The improvement was very little between 6:00 a.m. and 9:00 a.m. due to lower solar intensity. The noticeable productivity of the power production started around 5 am due to the contribution of solar irradiation and increased at a high rate to reach its maximum during the day (9:00 to 15:00). The differences between the SCPP and SCPP-PV can reach up to onefold. The maximum power production 
coincides with the maximum solar radiation. The maximum power production was increased from $142 \mathrm{~kW}$ in the SCPP to $158 \mathrm{~kW}$ in the SCPP-PV system.

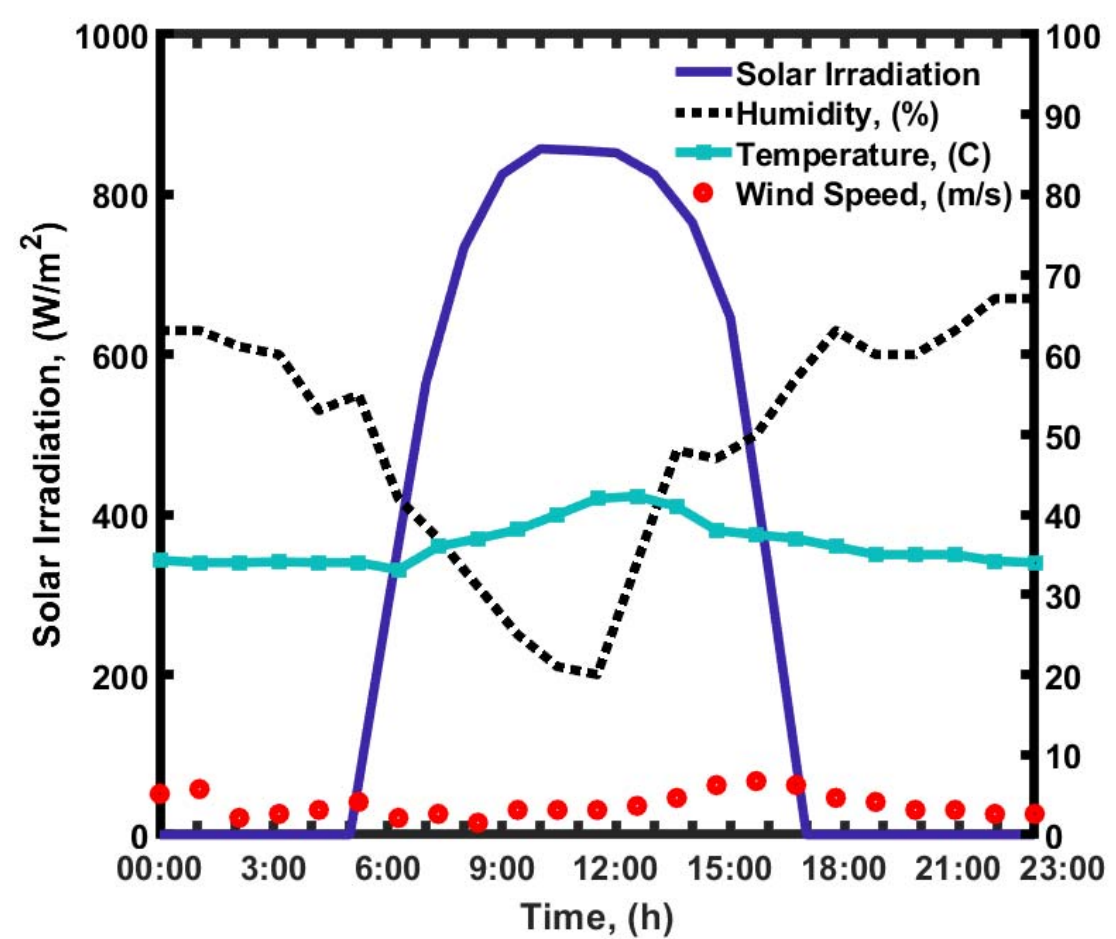

Figure 3. 24-hour weather profile at Doha International Airport, Doha, Qatar (latitude: $25^{\circ} 17^{\prime} 9.9816^{\prime \prime} \mathrm{N}$, longitude: $\left.51^{\circ} 32^{\prime} 5.3412^{\prime \prime} \mathrm{E}\right)$.

Figure $4 \mathrm{~B}$ also shows that the maximum amount of water generated slightly increased from 56 to 62 by adding the PV to the SCPP. The profile for the desalinated water was increasing as a result of increasing the solar radiation, with few variations, due to changes in wind speed. There is a direct correlation between the air velocity inside the solar chimney, power production, and temperature. When the air is heated up, its velocity increases, leading to higher power and desalinated power production. Despite this interesting feature of the SCPP, the economy remains the biggest obstacle to be solved. Therefore, we proposed in the present design to integrate the traditional PV power system with the SCPP to gain the following advantage: an increase in the temperature profile of the air under the collector by heating the air before entering the collector.

\subsection{Annual Power and Water Production in the SCPP and PV-SCPP Systems}

Table 3 summarizes the monthly power production for the basic SCPP and PV-SCPP systems. The power production for January was increased by 1.6-fold, from $29,516 \mathrm{kWh}$ for the SCPP to $46,467 \mathrm{kWh}$ for the PV-SCPP design. The total area of the PV was determined to be $500 \mathrm{~m}^{2}$, which potentially provided $42,888 \mathrm{kWh}$ before integration. In June, the highest energy output achieved was $34,419 \mathrm{kWh}$ for the SCPP and increased further until it reached 38,992 when the PV-SCPP was used.

The annual energy production of the PV-SCPP was determined to be $494,100 \mathrm{kWh}$, which is $30 \%$ higher than the basic SCPP $(380,263 \mathrm{kWh})$. This is a significant increase, leading to reducing the levelized cost of energy (LCOE) and improving the process economy.

After the integration, moderate cooling is achieved via heat exchange with the natural drafting air that enters the PV-SCPP design. This is truly a win-win situation where the turbine inside the PV-SCPP generated higher power output due to heating up the air via the integrated PV. At the same time, the heated-up air moderately cooled the PV, leading to increasing its efficiency by $2 \%$, as expected and in agreement with previous studies $[19,23]$. Increasing the internal temperature of the air is directly proportional to the amount of 
desalinated water. The desalinated water increased from 8961 to 11,945 tons when the PV-SCPP design was employed for January. As with the energy production, the amount of distilled water peaked in the summertime and reached a value of 15,662 tons. The annual amount of distilled water was increased from 139,443 to 163,143 tons, achieving a $17 \%$ increase. It is worth noting, despite the higher amount of water production being proportionally related to power production, the maximum distilled water produced was in July, while the maximum energy produced was in June. This is due to the higher humidity ratio for July compared to June.

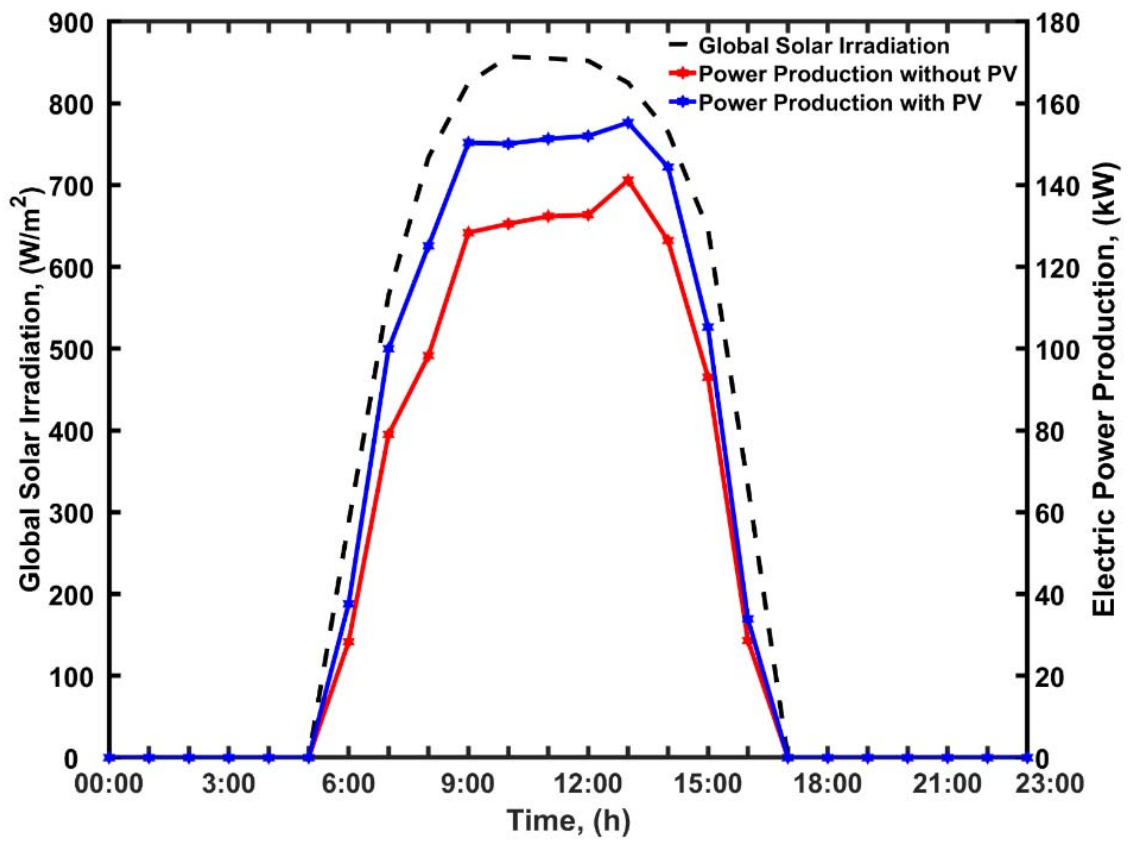

(A)

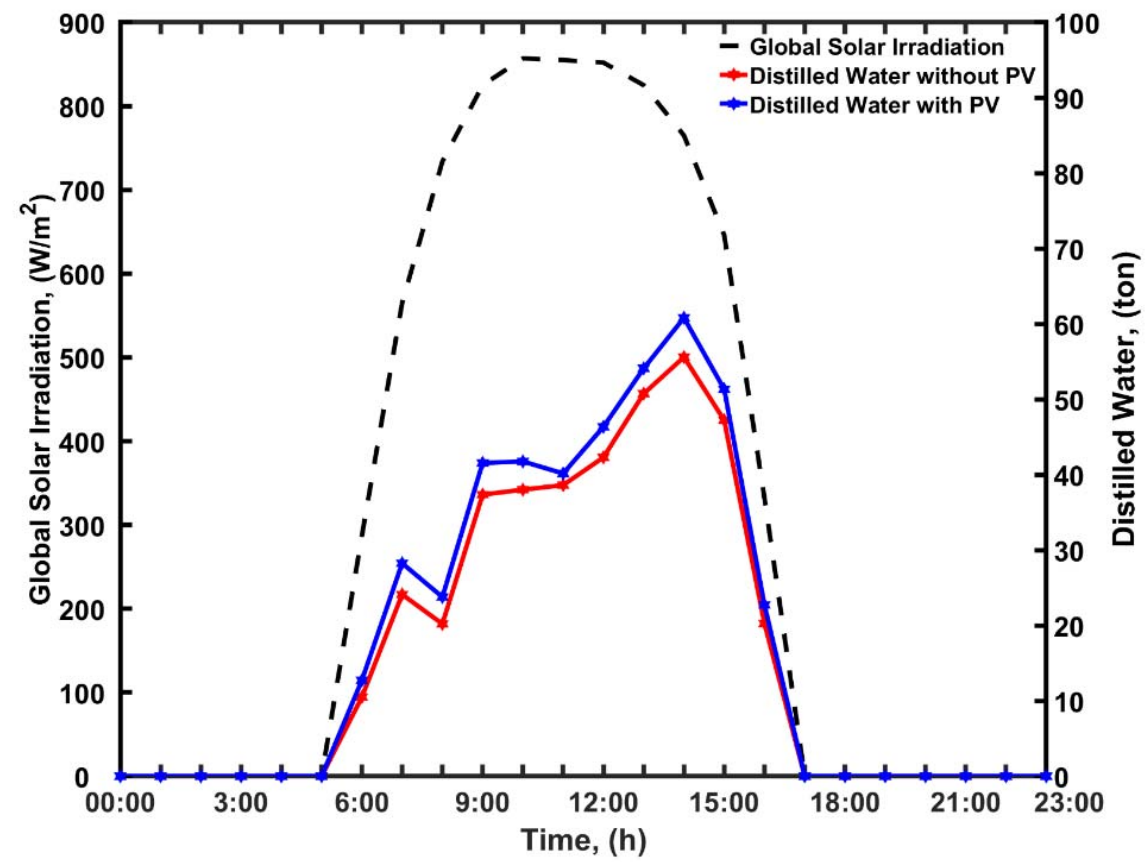

(B)

Figure 4. (A) Energy generation in SCPP and PV-SCPP; (B) desalinated water production in SCPP and PV-SCPP. 
Table 3. SCPP monthly production of electricity and water with and without two-meter PV length integration.

\begin{tabular}{cccccc}
\hline \multirow{2}{*}{ Month } & $\begin{array}{c}\text { Solar } \\
\text { Irradiation } \\
\left(\mathbf{k W h} / \mathbf{m}^{\mathbf{2}}\right)\end{array}$ & \multicolumn{2}{c}{ Electric Energy, (kWh) } & \multicolumn{2}{c}{ Water Production (ton) } \\
\cline { 3 - 6 } & 203 & $\mathbf{S C P P}$ & $\mathbf{P V - S C P P}$ & SCPP & PV-SCPP \\
\hline January & 24,516 & 46,467 & 8961 & 11,945 \\
February & 261 & 28,348 & 41,471 & 10,244 & 13,052 \\
March & 272 & 32,543 & 45,710 & 11,499 & 14,286 \\
April & 289 & 32,119 & 40,852 & 13,501 & 15,761 \\
May & 325 & 35,510 & 42,148 & 13,339 & 14,836 \\
June & 321 & 34,129 & 38,992 & 14,511 & 15,662 \\
July & 310 & 34,068 & 38,168 & 14,817 & 15,862 \\
August & 293 & 31,473 & 37,224 & 13,177 & 14,377 \\
September & 263 & 30,663 & 39,735 & 11,412 & 12,704 \\
October & 230 & 29,553 & 41,712 & 9558 & 11,230 \\
November & 208 & 27,921 & 42,226 & 9339 & 11,634 \\
December & 3,218 & 380,263 & 494,100 & 139,443 & 11,795 \\
Total & & & & & 163,143 \\
\hline
\end{tabular}

The high energy output and the amount of distilled water are likely related to the solar radiation and are less dependent on the surrounding temperature of the air. As seen from Figure 5, there was a direct relationship between the energy output and the outside temperature for the period of 6:00 to 9:00 a.m.

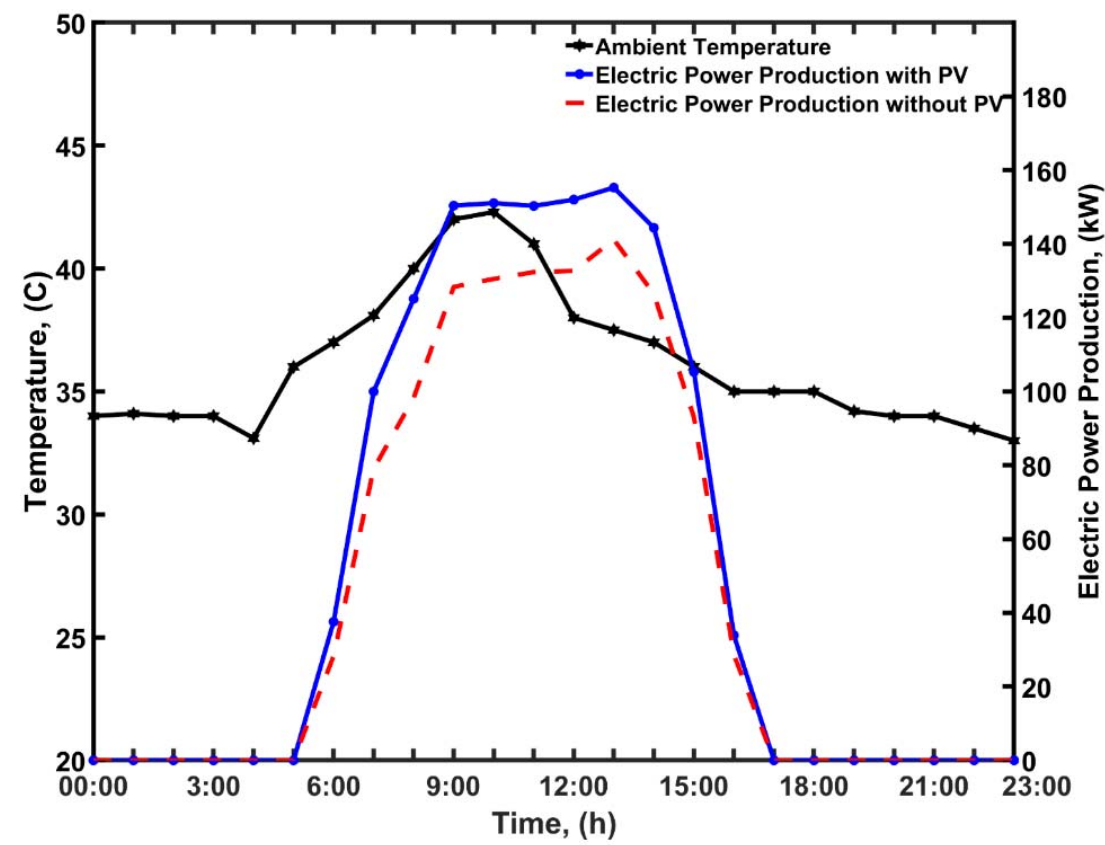

Figure 5. The influence of ambient temperature on the performance of the PV-SCPP and SCPP designs.

The increase in the outside temperature from 36 to $42{ }^{\circ} \mathrm{C}$, during the period of 6:00 to 9:00 a.m., was combined with increasing power generation from 0 to $150 \mathrm{kWh}$. However, when the outside temperature decreased from $42{ }^{\circ} \mathrm{C}$ to $36^{\circ} \mathrm{C}$, during the period of 9:00 a.m. to 3:00 p.m., the energy output leveled at $150 \mathrm{kWh}$, showing that solar radiation plays a major role in the production and minimizes the effect of the outside temperature. This opens a new possibility that SCPP can operate even in colder weather conditions if there is enough solar radiation to heat the air underneath the collector zone. The increased power production and the amount of desalinated water agree with the results obtained by Kiwan et al. [20], Elghamry et al. [29], and Haghighat et al. [30]. Kiwan et al. [20] 
investigated the submerged PV panels underneath the collector and not at the entrance, contrary to this study. The submerged PV panels inside the SC generated $45.35 \%$ more electricity annually than the SCPP standing alone. In another interesting experimental study, Elghamry et al. [29] installed the PV inside the solar chimney, resulting in producing $70 \%$ more power than a standing alone reference PV. Haghighat et al. [30] presented a CFD model that studies the integration of the SCPP, resulting in increasing the power from $267 \mathrm{~W}$ in the standing alone SCPP to $300.4 \mathrm{~W}$ when consolidated with the SCPP.

\subsection{The Influence of Temperature and Air Velocity on the Performance of SCPP and PV-SCPP Systems}

Figure $6 \mathrm{~A}, \mathrm{~B}$ presents the effect of the ambient temperature and wind on the temperature and air velocity profiles inside the solar chimney before the air collides with the turbine. The velocity and temperature of the hot air increase as the solar radiation increases. The increases of these values (temperature and velocities) are proportional to the energy output. Since the curvature of both profiles is directly proportional to the solar radiation, we may conclude that solar radiation is the biggest factor responsible for the temperature and velocity profiles. Furthermore, there is a direct relationship between the air temperature and velocity before entering the turbine and the radius of the collector. The longer the path under the collector for the air to move, the longer the exposure of the air to solar radiation. However, other factors affect the values of the temperature and velocity increase, such as the collector diameter and its elevation from Earth's surface. The height and diameter of the collector used in this study were optimized in previous studies, and, therefore, we assume the solar radiation is the only factor affecting the physical properties of the air inside the collector. Furthermore, the air temperature and its velocity inside the collector are the major contributors to the energy output, along with other factors, such as the chimney height. This is similar to the mechanism in the shredded wind turbine.

\subsection{Economic and Environmental Analysis}

The PV-SCPP is a promising renewable technology for clean electricity production and provides desalinated water at zero energy consumption. The amount of electricity and water produced from the PV-SCPP would save GHG emissions generated from power and desalination plants. The standard value of $\mathrm{CO}_{2}$ emissions produced by a coal-fired power plant is reported to be $0.95 \mathrm{~kg} \mathrm{CO}_{2} \mathrm{eq}$. $/ \mathrm{kWh}$ [31]. We assume that the amount of produced water would reduce the load for reverse osmosis desalination plants. Therefore, we assume the reverse osmosis would emit $2 \mathrm{~kg} \mathrm{CO} 2 \mathrm{eq} /$ ton produced water. Therefore, the GHG emissions reduction is estimated by implementing the below equation:

Mass of $\mathrm{CO}_{2}(\mathrm{~kg})=\frac{0.95 \mathrm{CO}_{2} \mathrm{eq}}{\mathrm{kWh}}$.Electrical production $\mathrm{kWh}+\frac{2 \mathrm{CO}_{2} \mathrm{~kg}}{\text { Tons water }}$. Tons of distilled wate

The comparative performance of the SCPP and PV-SCPP is presented in Table 4. The performance criteria for both designs include annual power production, potential GHG reduction, and desalinated production. The data show that the PV-SCPP generates 30\% more electricity in comparison with the SCPP, while the amount of desalinated produced water was $17 \%$ higher. The integration of the PV panels to the SCPP provided higher power output, which eventually replaced part of the local electrical production from the classical power plant. This replacement reduced the amount of GHG production by $30 \%$ (Table 4). Additional replacement comes from desalinated water since it replaces the water produced from RO plants. The GHG reduction from desalinated water is only valid in geographical locations where major water suppliers are reverse osmosis plants. The overall GHG reduction for the novel design corresponds to 820 tons annually, significantly higher than the reported values by other studies.

The natural water precipitation in Qatar and the fresh groundwater was estimated to be $71-\mathrm{m}^{3}$ / annually per capita in 2005 [32] This value is greatly under the water poverty range of $1000-\mathrm{m}^{3}$ / annually per capita. Therefore, water desalination continues to be the main source of Qatar's freshwater. Reverse osmosis and thermal desalination technologies 
are the major providers of freshwater in Qatar. Therefore, the SCPP technologies, and, in particular, the current novel design, would have a significant application in Qatar in terms of sustainable, environmentally friendly water production. Qatar is also committed to reducing the GHG by investing in decarbonization technologies. The PV-SCPP would provide almost zero operating cost energy and water production technology with a significant reduction of the GHG.

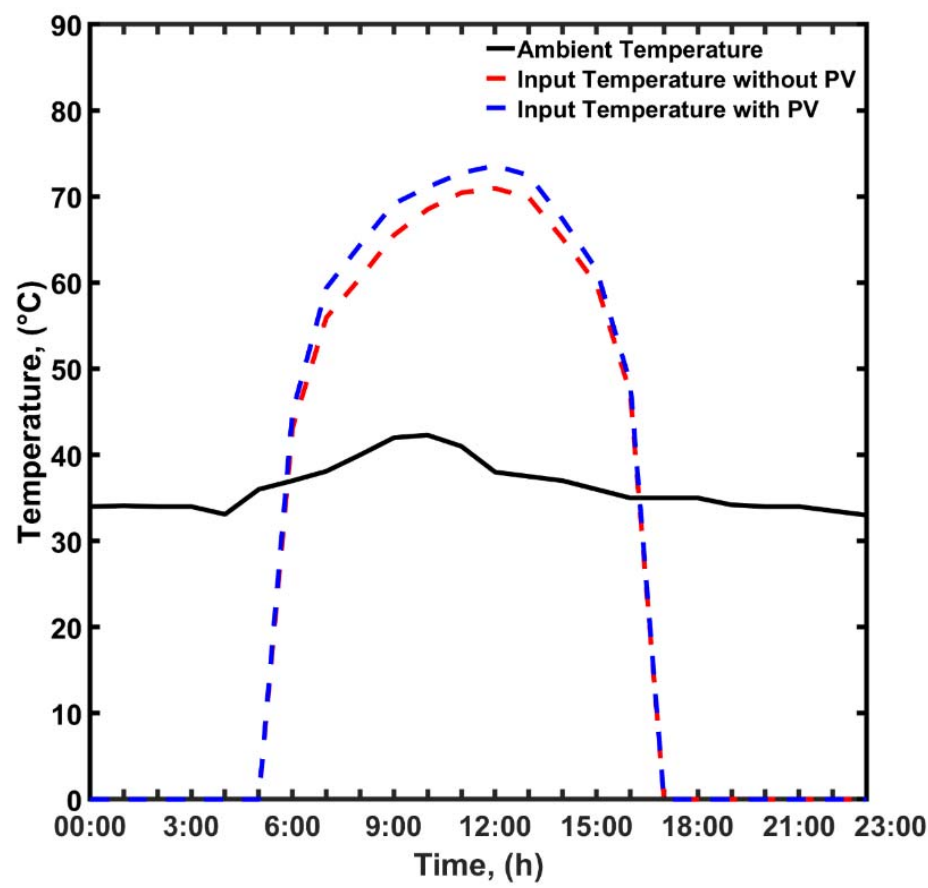

(A)

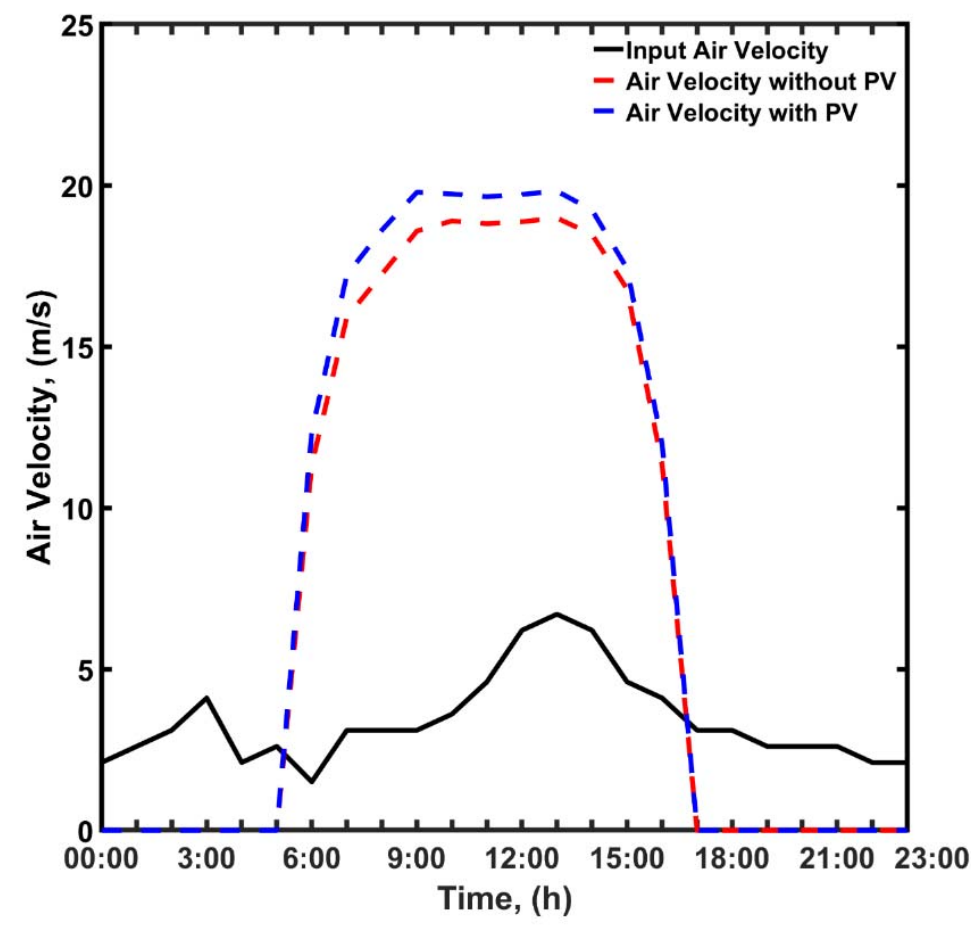

(B)

Figure 6. (A)The temperature profile of air before entering the turbine for SCPP and PV-SCPP system; (B) the air velocity profile air before entering the turbine for SCPP and PV-SCPP system. 
Table 4. Comparative performance of the PV-SCPP versus the conventional SCPP.

\begin{tabular}{cccc}
\hline Performance Criteria & SCPP & PV-SCPP & $\begin{array}{c}\text { (\%) Increase } \\
(+) / \text { Decrease (-) }\end{array}$ \\
\hline $\begin{array}{ccc}\text { Annual power production, (kWh/year) } \\
\text { Desalinated water production (tons/year) }\end{array}$ & 380,236 & 494,100 & +29 \\
The corresponding CO emission reduction & 36,443 & 163,143 & +17 \\
$\quad$ (tons / year) & 361 & 459 & +29 \\
LCOE, \$/kWh & 1.86 & 1.50 & -36 \\
Capital cost, \$ MM & 1.25 & 1.50 & -20 \\
\hline
\end{tabular}

The present study is a continuation of the SCPP developed and optimized by Abdelsalam et al. $[17,18]$ with the final purpose of integrating the PV with the SCPP in a hybrid design. Hence, we will use the same costs as developed previously by Abdelsalam et al. [17] with marginal variations. Abdelsalam et al. [17] presented that the capital investment of the SCPP corresponds to US $\$ 1.25$ million while producing 441,440 MW electricity. The capital investment estimation by Abdelsalam et al. [17] included all the SCPP components as well as the installation and labor costs.

Despite the seawater desalination dramatically solving the need for freshwater for Qatar, its cost still exhibits the biggest challenge for sustainability. Qatar has 12 desalination plants, with the production costs corresponding to $\$ 0.82, \$ 1.04$, and $\$ 0.95$ per meter cube for reverse osmosis, multi-stage flash distillation, and multi-effect distillation, respectively. The energy demand is high and corresponds to $75 \%$ of the desalination cost [33].

The proposed design outcomes align with Qatar's vision of 2030 [34] for sustainable development for food and energy security. The novel design was proposed in the location with other existing desalination plants in Qatar. The hybrid design is not supposed to replace the existing desalination plants but rather is a complementary plant with almost zero cost for each meter of cubic water and nearly zero GHG emissions. If the plant is to be constructed, it will contribute to 163,143 tons/year.

The SCPP technology exists commercially but at a very limited scale due to the high cost of capital and operating cost. The main obstacle for widely accepting the technology is reducing the initial and operating costs. This work introduces a new design that we proved to operate at a lower cost and improves the performance of the new proposed design: PV-SCPP. The new design, PV-SCPP, provides a solution for classical PV cooling, as well as the production of desalinated water at a low cost compared to reverse osmosis technologies. Therefore, the improved design would attract stakeholders and attract the venture capitalist. Hence, the PV-SCPP presents innovative opportunities for PV-SCPP commercialization due to lowering the LCOE, freshwater production, as well the GHG reduction.

\section{Conclusions}

The novel design integrates two renewable technologies (PV and SCPP) that achieve high energy efficiency, low-cost water desalination, and GHG reduction. The novel design offers a cooling mechanism of the PV with zero GHG emission compared to other cooling technologies. The cooling of the PV was essential to increase its efficiency, which added to the overall efficiency of the PV-SCPP. The economic aspect of the PV-SCPP design improved compared with the basic design when the SCPP was considered as a reference case. This would dramatically increase the technical readiness level of the technology and open new possibilities for future commercialization. The energy efficiency increased by increasing the overall electrical power output for both systems as well as increasing the power generation for the PV due to the cooling effect. During one day in summertime, the power improved for the novel design from $128 \mathrm{~kW}$ to $152 \mathrm{~kW}$. The corresponding annual electrical production improved from $380 \mathrm{MWh}$ to $494 \mathrm{MWh}$. Therefore, the novel design opens new possibilities for the commercial application of the SCPP due to lowering the LCOE, solving the water scarcity challenge, and reducing the GHG impact. Future work will focus on the design configuration of the turbine, its cost, and its durability. 
Author Contributions: Conceptualization, M.A., M.T. and E.A.; methodology, M.A., E.A.; software, H.A. and A.M.; validation, H.A. and A.M.; formal analysis, H.A. and A.M.; investigation, M.A.; resources, E.A.; data curation, H.A. and A.M.; writing-original draft preparation, M.A., E.A., F.A. and M.T.; writing-review and editing, M.A., E.A. and F.A.; visualization, A.M.; supervision, E.A.; project administration, M.A. All authors have read and agreed to the published version of the manuscript.

Funding: This research received no external funding.

Institutional Review Board Statement: Not applicable.

Informed Consent Statement: Not applicable.

Data Availability Statement: Not applicable.

Acknowledgments: The authors would like to the thank the Al Hussien Technical University, Amman, Jordan (www.htu.edu.jo, (accessed on 30 August 2021).) for their support in developing this work.

Conflicts of Interest: The authors declare no conflict of interest.

\section{Nomenclature}

\begin{tabular}{|c|c|}
\hline A & Area $\left(\mathrm{m}^{2}\right)$ \\
\hline$A_{m}$ & Area of PV panel $\left(\mathrm{m}^{2}\right)$ \\
\hline $\mathrm{C}_{\mathrm{f}}$ & Turbine efficiency, 0.42 \\
\hline $\mathrm{cp}$ & Specific heat capacity $\left(\mathrm{J} \mathrm{kg}^{-1} \mathrm{~K}^{-1}\right)$ \\
\hline $\mathrm{D}$ & Diameter $(\mathrm{m})$ \\
\hline dh & Hydraulic diameter (m) \\
\hline g & Gravity acceleration $\left(\mathrm{m} \mathrm{s}^{-2}\right)$ \\
\hline $\mathrm{H}$ & Height (m) \\
\hline $\mathrm{h}$ & Heat transfer coefficient $\left(\mathrm{W} \mathrm{m}^{-2} \mathrm{~K}^{-1}\right)$ \\
\hline hfg & Latent heat of water evaporation, $\left(\mathrm{W} \mathrm{m}^{-2} \mathrm{~K}^{-1}\right)$ \\
\hline I & Intensity of solar irradiation $\left(\mathrm{W} \mathrm{m}^{-2}\right)$ \\
\hline $\mathrm{i}$ & Enthalpy (kJ) \\
\hline k & Thermal conductivity of air $\left(\mathrm{W} \mathrm{m}{ }^{-1} \mathrm{~K}^{-1}\right)$ \\
\hline $\bar{m}$ & Mass flow rate $\left(\mathrm{kg} \mathrm{s}^{-1}\right)$ \\
\hline NOCT & Nominal operating cell temperature $(\mathrm{K})$ \\
\hline $\mathrm{P}_{\text {elc }}$ & Electrical power $(\mathrm{W})$ \\
\hline PV & Photovoltaic \\
\hline q & Heat transfer rate $\left(\mathrm{W} \mathrm{m}^{-2}\right)$ \\
\hline $\mathrm{Q}_{\text {out }}$ & Heat transfer between the outside and chimney wall (W) \\
\hline $\mathrm{r}$ & Radius (m) \\
\hline $\mathrm{T}$ & Temperature (K) \\
\hline $\mathrm{V}_{\mathrm{ch}}$ & Air velocity entering the chimney, $\left(\mathrm{m} \mathrm{s}^{-1}\right)$ \\
\hline $\mathrm{V}_{\mathrm{w}}$ & Wind velocity $\left(\mathrm{m} \mathrm{s}^{-1}\right)$ \\
\hline \multicolumn{2}{|c|}{ Greek Symbols } \\
\hline A & Absorptivity \\
\hline$\beta$ & Packing factor, Temperature coefficient $\left(\mathrm{K}^{-1}\right)$ \\
\hline$\eta$ & System utilization factor \\
\hline $\mathrm{P}$ & Density $\left(\mathrm{kg} \mathrm{m}^{-3}\right)$ \\
\hline$\tau$ & Transmissivity \\
\hline$\omega$ & Relative humidity \\
\hline \multicolumn{2}{|c|}{ Subscripts } \\
\hline abs & Absorber \\
\hline air & Air \\
\hline c & Convective heat transfer \\
\hline $\mathrm{cd}$ & Condensated water \\
\hline ch & Chimney \\
\hline cnd & Conductive heat transfer \\
\hline col & Collector \\
\hline
\end{tabular}




$\begin{array}{ll}\text { e } & \text { Evaporation } \\ \text { ent } & \text { Entrance } \\ \text { gls } & \text { Glass } \\ \text { out } & \text { Outside } \\ \mathrm{r} & \text { Radiative heat transfer } \\ \text { sky } & \text { Sky } \\ \text { ted } & \text { PV Tedlar } \\ \text { wtr } & \text { Water }\end{array}$

\section{References}

1. Islam, M.A.; Che, H.S.; Hasanuzzaman, M.; Rahim, N.A. Energy demand forecasting. In Energy for Sustainable Development: Demand, Supply, Conversion and Management; Elsevier: Amsterdam, The Netherlands, 2019; pp. 105-123.

2. Vohra, K.; Vodonos, A.; Schwartz, J.; Marais, E.A.; Sulprizio, M.P.; Mickley, L.J. Global mortality from outdoor fine particle pollution generated by fossil fuel combustion: Results from GEOS-Chem. Environ. Res. 2021, 195, 110754. [CrossRef]

3. Al-Mamun, M.R.; Karim, M.N.; Nitun, N.A.; Kader, S.; Islam, M.S.; Khan, M.Z.H. Photocatalytic performance assessment of GO and $\mathrm{Ag}$ co-synthesized $\mathrm{TiO} 2$ nanocomposite for the removal of methyl orange dye under solar irradiation. Environ. Technol. Innov. 2021, 22, 101537. [CrossRef]

4. Salameh, T.; Ghenai, C.; Merabet, A.; Alkasrawi, M. Techno-economical optimization of an integrated stand-alone hybrid solar PV tracking and diesel generator power system in Khorfakkan, United Arab Emirates. Energy 2020, 190, 116475. [CrossRef]

5. Tawalbeh, M.; Al-Othman, A.; Kafiah, F.; Abdelsalam, E.; Almomani, F.; Alkasrawi, M. Environmental impacts of solar photovoltaic systems: A critical review of recent progress and future outlook. Sci. Total Environ. 2020, 759, 143528. [CrossRef] [PubMed]

6. Rosa, L.; Chiarelli, D.D.; Rulli, M.C.; Dell'Angelo, J.; D’Odorico, P. Global agricultural economic water scarcity. Sci. Adv. 2020, 6, eaaz6031. [CrossRef] [PubMed]

7. Jia, X.; Klemeš, J.J.; Alwi, S.R.W.; Varbanov, P.S. Regional Water Resources Assessment using Water Scarcity Pinch Analysis. Resour. Conserv. Recycl. 2020, 157, 104749. [CrossRef]

8. Langarudi, S.P.; Maxwell, C.M.; Fernald, A.G. Integrated Policy Solutions for Water Scarcity in Agricultural Communities of the American Southwest. Systems 2021, 9, 26. [CrossRef]

9. Garrick, D.; Iseman, T.; Gilson, G.; Brozovic, N.; O’Donnell, E.; Matthews, N.; Miralles-Wilhelm, F.; Wight, C.; Young, W. Scalable solutions to freshwater scarcity: Advancing theories of change to incentivise sustainable water use. Water Secur. 2020, 9, 100055. [CrossRef]

10. Srimuk, P.; Su, X.; Yoon, J.; Aurbach, D.; Presser, V. Charge-transfer materials for electrochemical water desalination, ion separation and the recovery of elements. Nat. Rev. Mater. 2020, 5, 517-538. [CrossRef]

11. Alkaisi, A.; Mossad, R.; Sharifian-Barforoush, A. A Review of the Water Desalination Systems Integrated with Renewable Energy. Energy Procedia 2017, 110, 268-274. [CrossRef]

12. Alhaj, M.; Al-Ghamdi, S.G. Why is powering thermal desalination with concentrated solar power expensive? assessing economic feasibility and market commercialization barriers. Sol. Energy 2019, 189, 480-490. [CrossRef]

13. Tawalbeh, M.; Al-Othman, A.; Singh, K.; Douba, I.; Kabakebji, D.; Alkasrawi, M. Microbial desalination cells for water purification and power generation: A critical review. Energy 2020, 209, 118493. [CrossRef]

14. Zhou, X.; Wang, F.; Ochieng, R.M. A review of solar chimney power technology. Renew. Sustain. Energy Rev. 2010, 14, 2315-2338. [CrossRef]

15. Kasaeian, A.B.; Molana, S.; Rahmani, K.; Wen, D. A review on solar chimney systems. Renew. Sustain. Energy Rev. 2017, 67, 954-987. [CrossRef]

16. Schlaich, J. The solar chimney: Electricity from the sun, Edition Axel Menges, Stuttgart, Germany, 1995.[2] ROBERT R. Span. Sol. Chimney Nears Complet. MPS Rev. 1981, 6, 21-23.

17. Abdelsalam, E.; Kafiah, F.; Alkasrawi, M.; Al-Hinti, I.; Azzam, A. Economic Study of Solar Chimney Power-Water Distillation Plant (SCPWDP). Energies 2020, 13, 2789. [CrossRef]

18. Abdelsalam, E.; Kafiah, F.; Tawalbeh, M.; Almomani, F.; Azzam, A.; Alzoubi, I.; Alkasrawi, M. Performance analysis of hybrid solar chimney-power plant for power production and seawater desalination: A sustainable approach. Int. J. Energy Res. 2020, 45, er.6004. [CrossRef]

19. Kiwan, S.; Salam, Q.I.A. Solar chimney power-water distillation plant (SCPWDP). Desalination 2018, 445, 105-114. [CrossRef]

20. Kiwan, S.; Al-Nimr, M.; Salim, I. A hybrid solar chimney/photovoltaic thermal system for direct electric power production and water distillation. Sustain. Energy Technol. Assess. 2020, 38, 100680. [CrossRef]

21. Rashidi, S.; Esfahani, J.A.; Hosseinirad, E. Assessment of solar chimney combined with phase change materials. J. Taiwan Inst. Chem. Eng. 2021, 124, 341-350. [CrossRef]

22. Aliaga, D.M.; Feick, R.; Brooks, W.K.; Mery, M.; Gers, R.; Levi, J.F.; Romero, C.P. Modified solar chimney configuration with a heat exchanger: Experiment and CFD simulation. Therm. Sci. Eng. Prog. 2021, 22, 100850. [CrossRef] 
23. Zuo, L.; Liu, Z.; Ding, L.; Qu, N.; Dai, P.; Xu, B.; Yuan, Y. Performance analysis of a wind supercharging solar chimney power plant combined with thermal plant for power and freshwater generation. Energy Convers. Manag. 2020, 204, 112282. [CrossRef]

24. Abdelsalam, E.; Kafiah, F.; Almomani, F.; Tawalbeh, M.; Kiswani, S.; Khasawneh, A.; Ibrahim, D.; Alkasrawi, M. An Innovative Design of a Solar Double-Chimney Power Plant for Electricity Generation. Energies 2021, 14, 6235. [CrossRef]

25. Al-Waked, R.; Behnia, M. Enhancing performance of wet cooling towers. Energy Convers. Manag. 2007, 48, 2638-2648. [CrossRef]

26. Slimani, M.E.A.; Amirat, M.; Kurucz, I.; Bahria, S.; Hamidat, A.; Chaouch, W.B. A detailed thermal-electrical model of three photovoltaic/thermal (PV/T) hybrid air collectors and photovoltaic (PV) module: Comparative study under Algiers climatic conditions. Energy Convers. Manag. 2017, 133, 458-476. [CrossRef]

27. Zuo, L.; Zheng, Y.; Li, Z.; Sha, Y. Solar chimneys integrated with sea water desalination. Desalination 2011, 276, 207-213. [CrossRef]

28. Nizetic, S.; Ninic, N.; Klarin, B. Analysis and feasibility of implementing solar chimney power plants in the Mediterranean region. Energy 2008, 33, 1680-1690. [CrossRef]

29. Elghamry, R.; Hassan, H. An experimental work on the impact of new combinations of solar chimney, photovoltaic and geothermal air tube on building cooling and ventilation. Sol. Energy 2020, 205, 142-153. [CrossRef]

30. Haghighat, S.; Kasaeian, A.; Pourfayaz, F.; Shahdost, B.M. Fluid dynamics analysis for different photovoltaic panel locations in solar chimney. Energy Convers. Manag. 2019, 191, 71-79. [CrossRef]

31. Müller, L.J.; Kätelhön, A.; Bringezu, S.; McCoy, S.; Suh, S.; Edwards, R.; Sick, V.; Kaiser, S.; Cuéllar-Franca, R.; El Khamlichi, A.; et al. The carbon footprint of the carbon feedstock $\mathrm{CO}_{2}$. Energy Environ. Sci. 2020, 13, 2979-2992. [CrossRef]

32. Alhaj, M.; Mohammed, S.; Darwish, M.; Hassan, A.; Al-Ghamdi, S.G. A review of Qatar's water resources, consumption and virtual water trade. Desalin. Water Treat. 2017, 90, 70-85. [CrossRef]

33. Mannan, M.; Alhaj, M.; Mabrouk, A.N.; Al-Ghamdi, S.G. Examining the life-cycle environmental impacts of desalination: A case study in the State of Qatar. Desalination 2019, 452, 238-246. [CrossRef]

34. Qatar National Vision 2030. Available online: https:/ / www.psa.gov.qa/en/qnv1/pages/default.aspx (accessed on 22 October 2021). 